\title{
UPAYA MENGURANGI KEPADATAN NARAPIDANA DALAM LEMBAGA PEMASYARAKATAN DI INDONESIA
}

\author{
Galih Puji Mulyonoㄹ, Barda Nawawi Arief 2 \\ Program Studi Magister IImu Hukum, Fakultas Hukum \\ Universitas Diponegoro \\ ena.feriana@yahoo.co.id
}

\begin{abstract}
ABSTRAK
Pemasyarakatan merupakan lembaga pelaksana pidana penjara di Indonesia dilaksanakan menggunakan sistem pembinaan narapidana dalam Lembaga Pemasyarakatan. Kondisi lembaga pemasyarakatan di Indonesia saat ini mengalami kepadatan narapidana. Kondisi kelebihan penghuni di dalam lembaga pemasyarakatan, berakibat pada keterbatasan atau bahkan kekurangan berbagai fasilitas umum maupun fasilitas khusus yang disediakan dan diperuntukkan narapidana di lembaga pemasyarakatan, keadaan tersebut dapat memicu terjadinya berbagai permasalahan dalam lembaga pemasyarakatan. Oleh karena itu, diperlukan suatu upaya mengurangi kepadatan narapidana dalam lembaga pemasyarakatan di Indonesia. Metode penelitian yang digunakan dalam penelitian ini ialah jenis penelitian normatif (doctrinal). Strategi pembinaan dalam upaya mengurangi kepadatan narapidana di lembaga pemasyarakatan saat ini masih belum maksimal. Kajian komparasi terhadap upaya mengurangi kepadatan narapidana dengan model Good Time Allowance di negara asing antara lain dalam undangundang negara Wyoming (AS), Republik Filipina, Montana (AS). Model Good Time Allowance adalah pengurangan masa menjalani pidana dengan melakukan suatu pekerjaan baik, dapat memberikan motivasi kepada narapidana dengan melakukan suatu pekerjaan baik untuk berkomitmen menjadi baik dengan penghargaan pengurangan masa menjalani pidana.
\end{abstract}

Kata Kunci: Kepadatan; Lembaga Pemasyarakatan; Narapidana

\footnotetext{
${ }^{1}$ Mahasiswa Program Studi Magister IImu Hukum UNDIP

2 Dosen Program Studi Magister IImu Hukum UNDIP
} 


\section{A. PENDAHULUAN}

\section{Latar Belakang}

Lembaga Pemasyarakatan merupakan lembaga pelaksana pidana penjara di Indonesia dengan sistem pemasyarakatan. Adanya sistem pemasyarakatan memberikan makna yang penting bagi pembangunan sistem hukum pidana bidang pelaksana pidana di Indonesia. Sistem pemasyarakatan merupakan rangkaian kesatuan penegakan hukum pidana. Oleh karena itu, pelaksanaannya tidak dapat dipisahkan pengembangan konsepsi umum mengenai sistem pemidanaan. ${ }^{3}$ Artinya bahwa sistem pemasyarakatan berkaitan erat dengan pelaksanaan pidana penjara yang dilatar belakangi oleh sistem pemidanaan sebagai penjatuhan pidana.

Membicarakan hubungan antara penghukuman atau pemidanaan dengan pemasyarakatan, Sudarto melihat bahwa,

"Masalah Penghukuman dan pemasyarakatan merupakan bidang politik kriminal yang belum mendapatkan perhatian. Politik kriminal secara singkat dapat diartikan sebagai usaha yang rasionil dari masyarakat untuk menanggulangi kejahatan. Ini mencangkup kegiatan pembentukan undang-undang pidana, aktivitas dari kepolisian, kejaksaan, pengadilan dan aparat eksekusi, disamping usaha-usaha yang tidak menggunakan hukum pidana." 4

\footnotetext{
3 Dwidja Priyatno, Sistem Pelaksana Pidana Penjara di Indonesia, (Bandung: Refika Aditama), 2013, halaman 103.

${ }^{4}$ Sudarto, Kapita Selekta Hukum Pidana, (Bandung: Alumni), 1981, halaman 73.
}

Oleh karena itu, mengaitkan masalah hubungan antara pemidanaan dengan pemasyarakatan harus dikembalikan konsep rasionalitas mekanisme upaya penanggulangan kejahatan. Fokus dari upaya penanggulangan kejahatan tidak hanya pada mencegah dan menanggulangi kejahatan tetapi juga dalam kebijakan sistem pemidanaan yang berorientasi pemasyarakatan. Perkembangan di lembaga pemasyarakatan dewasa ini mengalami problematika dimana salah satu permasalahan dan terdapat sebagian lembaga pemasyarakatan di Indonesia yaitu masalah kepadatan narapidana.

Kondisi lembaga pemasyarakatan di Indonesia terjadi kepadatan dimana perbandingan jumlah penghuni lembaga pemasyarakatan dan kapasitas lembaga pemasyarakatan yang tidak sebanding jumlahnya. Kepadatan narapidana dalam lembaga pemasyarakatan terjadi oleh beberapa faktor penyebab. Namun terdapat faktor perlu mendapat perhatian khusus penyebab kepadatan narapidana di lembaga pemasyarakatan adalah sistem pemidanaan. Faktor penyebab kepadatan narapidana di lembaga pemasyarakatan terjadi bukan hanya karena meningkatnya kejahatan namun juga terjadi akibat dari sistem pemidanaan. 
Permasalahan yang timbul akibat dari kepadatan narapidana di lembaga pemasyarakatan antara lain:

"Pembinaan/ proses rehabilitasi narapidana tidak berjalan maksimal, sulitnya pengawasan dan pengamanan, memburuknya psikologis narapidana termasuk psikologis petugas, rentan konflik antar penghuni, rentan terjadi penyimpangan seksual, rusaknya sistem sanitasi, memburuknya kondisi kesehatan narapidana, dan terjadi pemborosan anggaran Negara akibat meningkatnya konsumsi makanan, air, dan pakaian." 5

Permasalahan di atas merupakan realitas yang dihadapi pemasyarakatan saat ini. Kondisi kelebihan daya tampung lembaga pemasyarakatan, berakibat pada keterbatasan atau bahkan kekurangan berbagai fasilitas umum maupun fasilitas khusus yang disediakan dan diperuntukkan narapidana, yang dapat memicu terjadinya berbagai permasalahan dalam lembaga pemasyarakatan.

Dewasa ini upaya mengurangi kepadatan narapidana dalam lembaga pemasyarakatan di Indonesia adalah menambah jumlah gedung atau lembaga pemasyarakatan baru dan pemberian hak narapidana dengan mempercepat reintegrasi narapidana di lembaga pemasyarakatan. Upaya mempercepat reintegrasi narapidana merupakan tindakan

\footnotetext{
${ }^{5}$ Kementerian Pemberdayagunaan Aparatur Negara dan Reformasi Birokrasi, Tenaga Administrasi akan Dialihkan Menjadi Sopir, (Jakarta: Kemenpan), diakses pada tanggal 21 Mei 2015. http://www.menpan.go.id.
}

setelah pemidanaan dalam sistem pemidanaan berupa asimilasi, cuti menjelang bebas, cuti bersyarat, pelepasan bersyarat, dan remisi. Upaya mempercepat reintegrasi narapidana adalah upaya hukum/ upaya penal sebagai upaya menghindarkan pengenaan pidana penjara yang lama beserta akibat negatif yang mengikutinya, upaya tersebut adalah tindakan setelah pemidanaan.

Perkembangan mempercepat rehabilitasi narapidana belum maksimal mengurangi kepadatan narapidana. Namun, menurut Dwidja Priyatno menyatakan bahwa

"Upaya mempercepat proses pembinaan
narapidana tersebut merupakan tolak ukur
peran strategis lembaga pemasyarakat
dalam keberhasilan proses pembinaan
narapidana dan hal ini direkomendasikan
sebagai alternatif yang yang paling banyak
mendatangkan manfaat terutama dalam
menanggulangangi dampak kepadatan
narapidana di lembaga pemasyarakatan. ${ }^{6}$ Keberadaan upaya mempercepat reintegrasi sangat penting menyangkut masalah pembinaan yang dilakukan oleh petugas lembaga pemasyarakatan dengan narapidana. Upaya mengurangi kepadatan narapidana di lembaga pemasyarakatan dengan mempercepat reintegrasi narapidana adalah bagian dari kebijakan sistem pemidanaan yang berorientasi dengan pemasyarakatan. Upaya optimalisasi peningkatan mempercepat reintegrasi

\footnotetext{
${ }^{6}$ Dwidja Priyatno, Op,cit, halaman 133.
} 
merupakan langkah strategis dalam mengatasi kepadatan narapidana di lembaga pemasyarakatan. Oleh karena itu, diperlukan suatu upaya optimalisasi peningkatan mengurangi kepadatan narapidana di lembaga pemasyarakatan dengan mencari alternatif tindakan setelah pemidanaan yaitu mempercepat reintegrasi.

Bertolak dasar pemikiran diatas, maka dalam penelitian ini mengusulkan gagasan upaya alternatif dalam program pembinaan narapidana dan dapat digunakan secara tidak langsung sebagai upaya mengurangi kepadatan narapidana dalam lembaga pemasyarakatan di Indonesia, yaitu dengan sistem Good Time Allowance (pengurangan masa pidana dengan melakukan suatu pekerjaan baik), yang diterapkan negara Republik Filipina, Wyoming (negara bagian Amerika Serikat) dan Montana (negara bagian Amerika Serikat). Good Time Allowance merupakan bentuk pembinaan dalam upaya mempercepat reintegrasi narapidana dengan pengurangan masa lama narapidana menjalani pidana di lembaga pemasyarakatan dengan melakukan pekerjaan baik.

\section{Permasalahan}

Maka berdasarkan pada uraian latar belakang di atas, selanjutnya permasalahan yang akan dibahas dalam penelitian ini adalah
1. Bagaimanakah upaya mengurangi kepadatan narapidana dalam lembaga pemasyarakatan di Indonesia saat ini?

2. Bagaimanakah upaya mengurangi kepadatan narapidana dalam lembaga pemasyarakatan di Indonesia yang akan datang?

\section{Metode Penelitian}

Dalam penelitian hukum terdapat beberapa pendekatan-pendekatan. Dengan pendekatan tersebut, peneliti akan mendapatkan informasi dari berbagai aspek mengenai isu yang sedang dicoba untuk dicari jawabannya. ${ }^{7}$ Jenis penelitian hukum dalam penulisan tesis ini adalah normatif (doctrinal). Penelitian hukum doktrinal adalah penelitianpenelitian atas hukum yang dikonsepsikan dan dikembangkan atas unsur doktrin yang dianut sang pengkonsep dan/ atau sang pengembangnya. ${ }^{8}$

Pengertian lain mengenai penelitian normatif (doctrinal) adalah suatu prosedur penelitian ilmiah untuk menemukan kebenaran berdasarkan logika keilmuan hukum dari sisi normatif. ${ }^{9}$ Dalam penelitian ini penulis menggunakan beberapa metode pendekatan,

\footnotetext{
7 Peter Mahmud Marzuki, Penelitian Hukum, (Jakarta: Kencana Prenada Media), 2014, halaman 133.

${ }^{8}$ Soetandyo Wignjosoebroto, Hukum Paradigma, Metode dan Dinamika Masalahnya, (Jakarta: Elsam dan Huma), 2002, halaman 147.

9 Johnny Ibrahim, Teori dan Metode Penelitian Normatif, (Malang: Bayumedia Publishing), 2010, halaman 57.
} 
metode pendekatan merupakan anak tangga untuk menentukan teori penelitian yang akan dipakai. Pendekatan penelitian dipakai untuk menentukan dari sisi mana obyek penelitian akan dikaji. ${ }^{10}$

Pendekatan yang digunakan dalam penelitian hukum ini, antara lain : pendekatan undang-undang (statute aproach); pendekatan konseptual (conceptual approach); dan pendekatan perbandingan (comparative approach).Penelitian ini melalui mencari dan mengumpulkan data yang diperlukan, difokuskan pada pokok-pokok permasalahan yang ada, sehingga dalam penelitian ini tidak terjadi penyimpangan dan kekaburan dalam pembahasan. Data yang digunakan dalam penelitian ini adalah data sekunder. Data sekunder dalam penelitian ini meliputi: bahan hukum primer; bahan hukum sekunder; dan bahan hukum tersier.

\section{Kerangka Teori}

Pemasyarakatan sebagai bagian dari sistem peradilan pidana terpadu dan bagian akhir dari sistem pemidanaan terdapat beberapa problematika. Problematika tersebut dapat dilihat dari masalah kepadatan narapidana dalam lembaga pemasyarakatan.

10 M. Syamsudin, Operasionalisasi Penelitian Hukum, (Jakarta: Raja Grafindo Persada), 2007, halaman 56.
Dengan demikian dalam menyelesaikan permasalahan di atas, teori yang digunakan sebagai pisau analisis yaitu:

1. Negara Hukum

Indonesia adalah negara hukum termuat dalam Undang-Undang Dasar Republik Indonesia Tahun 1945 Pasal 1 ayat 3 , yang memuat secara jelas bahwa "Negara Indonesia adalah Negara Hukum". ${ }^{11}$ Menurut Jimly Asshiddiqie makna yang terkandung dalam konsep negara hukum adalah

"Adanya pengakuan terhadap supremasi hukum dan konstitusi, dianutnya prinsip pemisahan dan pembatasan kekuasaan menurut sistem konstitusi, adanya jaminanjaminan Hak Asasi Manusia (HAM) dalam Undang-Undang Dasar 1945, equality before the law, kekuasaan pengadilan independen dan jaminan keadilan bagi setiap orang dari penyalahgunaan wewenang oleh penguasa."12

Pandangan A.V. Dicey memberikan 3 ciri dari sebuah negara sehingga dapat dikatakan sebagai negara hukum yaitu:

a. supremasi hukum;

b. persamaan kedudukan di depan hukum; dan

c. perlindungan dan pengakuan terhadap Hak Asasi Manusia. ${ }^{13}$

Sejalan dengan pandangan A.V. Dicey, terutama pada point c, Indonesia

${ }^{11}$ Undang-Undang Dasar Republik Indonesia Tahun 1945.

12 Jimly Asshiddiqie, Konstintusi dan Konstitusionalisme, (Jakarta: Konstitusi Pers), 2005, halaman 69.

${ }_{13}$ AV.Dicey,An Introduction to The Study of The Law of The Constitution,10th ed. (London: Macmillan Pres), 1973, page 202. 
sesuai dengan negara hukum unsur perlindungan dan pengakuan terhadap hak asasi manusia (HAM) hendak menghandirkan bahwa dalam rule of law, hak asasi manusia (HAM) merupakan bagian penting dalam negara. Negara menjamin perlindungan dan pengakuan terhadap hak asasi manusia (HAM) semua warga negara. Konstitusi menjamin perlindungan hak asasi manusia (HAM) warga negaranya, dalam konteks ini juga terhadap narapidana dalam lembaga pemasyarakan.

Asas equality before the law atau kedudukan yang sama dalam menghadapi hukum, supremasi hukum dan hak asasi manusia merupakan syarat dari konsep Negara hukum. ${ }^{14}$ Atas konsep itulah kebijakan-kebijakan menyangkut regulasi yang dikeluarkan oleh pemerintah serta implemantasi atas kebijakan-kebijakan mengedepankan aspek hak asasi manusia. Aturan tentang hak asasi manusia yang melekat pada setiap manusia diatur lewat seperangkat aturan hukum yang ada. ${ }^{15}$

Sistem pemasyarakatan dapat dilihat mengenai hak-hak narapidana, sebagai negara hukum hak-hak narapidana dilindungi

14 S.F. Marbun, Dimensi-Dimensi Pemikiran Hukum Administrasi Negara, (Yogyakarta: UUI Pers), 2001, halaman 8.

${ }^{15}$ A. Mansyur Effendi, Perkembangan Dimensi Hak Asasi Manusia dan Proses Dinamika Penyusunan Hukum Hak Asasi Manusia, (Bogor: Ghalia Indonesia), 2005, halaman 32. dan diayomi oleh aparat penegak hukum, khususnya staf di lembaga pemasyarakatan. Narapidana diayomi hak-haknya walaupun telah melanggar hukum, tindakan apapun yang dilakukan terhadap narapidana, baik berupa pembinaan ataupun tindakan lainya harus bersifat mengayomi dan tidak boleh bertentangan dengan tujuan sistem pemasyarakatan itu sendiri.

2. Kebijakan Kriminal

Pembinaan narapidana dengan sistem pemasyarakatan merupakan upaya penanggulangan kejahatan dalam arti luas yang merupakan bagian dari kebijakan kriminal atau politik kriminal. Kebijakan kriminal digunakan dalam perwujudan upaya mengurangi kepadatan narapidana dalam kebijakan sistem pemidanaan melalui tahaptahap yang direncanakan sebelumnya, yaitu tahap formulasi oleh pembuat undangundang, tahap aplikasi oleh kepolisian, kejaksaan, pengadilan dan tahap eksekusi. Dari ketiga tahap tersebut "akan diketahui bagaimana negara melalui alat-alat perlengkapannya memperlakukan para warganya yang kebetulan melakukan tindak pidana". ${ }^{16}$

\footnotetext{
${ }^{16}$ Nyoman Serikat Putra Jaya, Beberapa Permasalahan dalam Sistem Pemidanaan dalam Konsep KUHP Baru, (Semarang: Majalah Fakultas Hukum Universitas Diponegoro, No. 1), 1989, halaman 25.
} 
Sementara teori tentang kebijakan kriminal yang disampaikan Barda Nawawi Arief menyatakan bahwa:

"Dari uraian diatas, dapat dikatakan bahwa upaya mencari alternatif pidana penjara yang merupakan perwujudan kebijakan selektif dan limitatif. Kebijakan selektif dan limitatif bukan bertujuan menghapuskan pidana secara total, melainkan sekedar upaya menghindari sisi negatif dan kelemahan/ kekurangan dari pidana penjara." 17

$\mathrm{Hal}$ tersebut menjelaskan bahwa upaya mencari alternatif pelaksanaan pidana penjara baru dan suatu kegiatan pemikiran tentang perlakuan cara baru terhadap narapidana merupakan bagian dari kebijakan kriminal dengan kebijakan sistem pemidanaan. Upaya mengurangi kepadatan di lembaga pemasyarakatan ditekankan dalam draf resolusi PBB ke-8 mengenai "The Preventions of crime and treatment Offender" (Hanava-Cuba, 27 Agustus-7 September 1990), yang melahirkan standart minimum pidana penjara atau standard minimum rules (SMR), untuk tindakan-tindakan noncustodial oleh majelis Perserikatan BangsaBangsa (PBB) yang disebut juga The Tokyo Rules.

Menurut Barda Nawawi Arief tindakan non-custodial pada tahap setelah pemidanaan (post sentencing stage) adalah

17 Barda Nawawi Arief, Kapita Selekta Hukum Pidana, (Bandung: Citra Aditya Bakti), 2013, halaman 273. "untuk menghindari proses institusionalisasi dan membantu pelaku tindak pidana berinteraksi kembali ke masyarakat, pejabat yang berwenang harus mempunyai alternatif tindakan setelah pemidanaan ("postsentencing alternatives") yang cukup luas. (Rule 9.1 SMR)"18

\section{B. HASIL PENELITIAN DAN PEMBAHASAN}

1. Upaya Mengurangi Kepadatan Narapidana dalam Lembaga Pemasyarakatan di Indonesia Saat Ini

\subsection{Kondisi Kepadatan Narapidana dalam Lembaga Pemasyarakatan di Indonesia}

Pembinaan narapidana di lembaga pemasyarakatan merupakan hak bagi narapidana untuk mendapatkan pembinaan untuk bertaubat dan menjadi warga negara yang baik. Pemberian hak kepada narapidana untuk mendapat pembinaan tersebut merupakan bentuk perlindungan dan pengakuan hak asasi manusia sebagaimana diamanatkan dalam Undang-Undang Dasar Republik Indonesia Pasal 1 ayat 3, yang berbunyi bahwa "Negara Indonesia adalah Negara hukum."19 Makna yang terkandung Negara hukum ialah adanya pengakuan dan penjaminan unsur perlindungan dan pengakuan terhadap hak asasi manusia (HAM). Negara menjamin perlindungan dan

18 Barda Nawawi Arief, Perbandingan Hukum Pidana, (Jakarta: Raja Grafindo Persada), 2002, halaman 114.

${ }^{19}$ Undang-Undang Dasar Republik Indonesia Tahun 1945. 
pengakuan terhadap hak asasi manusia (HAM) semua warga negara. Konstitusi menjamin perlindungan hak asasi manusia (HAM) warga negaranya, dalam konteks ini juga terhadap narapidana dalam lembaga pemasyarakatan.

Dalam pandangan A.V. Dicey bahwa perlindungan hak Asasi manusia merupakan bagian dari negara hukum pengakuan dan perlindungan hak asasi manusia ini merupakan keharusan yang ada dalam negara hukum. Negara Indonesia sebagai negara hukum menjamin dan melindungi hak asasi manusia seluruh warganya termasuk dalam narapidana di lembaga pemasyarakatan tanpa memandang status warga tersebut. Pengakuan dan perlindungan hak asasi manusia oleh Negara digunakan dalam kebijakan menyangkut regulasi yang dikeluarkan pemerintah maupun implemantasi atas kebijakan-kebijakan Negara dengan mengedepankan aspek hak asasi manusia. Pembinaan narapidana di lembaga pemasyarakatan untuk dapat berubah menjadi baik dan diterima kembali ke dalam lingkungan masyarakat adalah hak dari narapidana dan hak dari warga masyarakat mendapatkan rasa aman dari pelaku tindak pidana yang berubah menjadi baik. Proses tersebut merupakan bagian kebijakan kriminal dalam upaya menanggulangi kejahatan dan perlindungan masyarakat.

Kebijakan kriminal menyangkup keseluruhan kebijakan perundang-undangan, fungsi aparat penegak hukum dan sistem peradilan pidana. Apabila dihubungkan dengan kebijakan kriminal upaya mengurangi kepadatan narapidana, maka secara luas dapat mencakup kebijakan sistem pemidanaan yang merupakan bagian dari pembaharuan hukum pidana dalam upaya mengurangi kepadatan narapidana. Kebijakan kriminal dapat digunakan sebagai perwujudan kebijakan dari penerapan pidana penjara dalam sistem pemidanaan yang berorientasi dengan pemasyarakatan maupun kebijakan selektif dan limitatif. Oleh karena itu, kebijakan sistem pemidanaan yang berorientasi dengan pemasyarakatan maupun kebijakan selektif dan limitatif akan mencegah terjadinya kepadatan narapidana.

Beberapa contoh lembaga pemasyarakatan di Indonesia yang mengalami kepadatan narapidana. Kondisi lembaga pemasyarakatan di atas mengalami kelebihan penghuni, kondisi tersebut juga semakin membuat tidak berimbang dengan jumlah penghuni di lembaga pemasyarakatan. Lembaga pemasyarakatan sebagai tempat hunian bagi tahanan dan narapidana maupun pegawai, memiliki kapasitas tertentu yang disesuaikan dengan pola bangun ruang lembaga pemasyarakatan. Penghuni yang menempati lembaga pemasyarakatan tersebut harus pula diimbangi dengan ketersediaan kapasitas hunian yang proporsional guna 
memaksimalkan pelaksanaan tugas dan fungsi pelayanan tahanan dan narapidana di lembaga pemasyarakatan. ${ }^{20}$

Kondisi kepadatan narapidana di lembaga pemasyarakatan merupakan kendala krisis bagi terwujudnya pembinaan narapidana yang terjadi di Indonesia selama ini. Kondisi krisis pengelolaan penjara harus memperhatikan 8 faktor penyebab krisis menurut Woolf, yakni:

"(1) Populasi penjara tinggi; (2) Kelebihan kapasitas; (3) kondisi Bad dalam penjara (untuk kedua narapidana dan petugas penjara); (4) understaffing; (5) Kerusuhan antara staf penjara; (6) Miskin keamanan; (7) "campuran beracun" dari jangka panjang dan tahanan hukuman seumur hidup dan tahanan mental terganggu; (8) Kerusuhan dan kerusakan lain dari kontrol atas tahanan." 21

Kondisi penghuni lembaga pemasyarakatan yang penuh sesak menimbulkan dampak negatif dengan tidak berjalanannya sistem pembinaan karena menimbulkan berbagai masalah sosial di dalam pemasyarakatan. Terjadinya berbagai kendala tersebut tidak mencerminkan asas persamaan perlakuan dan pelayanan dalam pemberian perlakuan dan pelayanan yang sama kepada narapidana tanpa membeda-bedakan orang sehingga menimbulkan konflik dalam lembaga pemasyarakatan. Patut diingat bahwa

\footnotetext{
20 Eko Soponyono, dkk., Realitas Penjara Indonesia 2, (Jakarta: Center for Detention Studies), 2015, halaman 21.

${ }^{21}$ Michael Cavadino and James Dignan, The Penal System an Introduction, (London: Sage Publications), 2003, page 10.
}

mempertimbangkan tujuan pemidanaan bahwa pidana untuk memperbaiki penjahat itu sendiri.

Kepadatan narapidana tersebut merupakan bagian kebijakan sosial, kebijakan kriminal dan kebijakan Bangnas/ Bangkumnas. Oleh karena itu dapat dikatakan bahwa upaya menanggulangi kepadatan narapidana dalam pembaharuan hukum pidana harus memperhatikan kebijakan-kebijakan tersebut.

\subsection{Bentuk-bentuk Kebijakan dalam Upaya Mengurangi Kepadatan Narapidana di Lembaga Pemasyarakatan Saat Ini}

Upaya mengurangi kepadatan narapidana dapat diartikan sebagai upaya negara dalam hal ini pemerintah melalui kebijakan kriminal. Akar penyebab tingginya tingkat penjatuhan pidana penjara dan kepadatan di lembaga pemasyarakatan hanya dapat diatasi secara berkelanjutan jika dianalisis dan dipahami dengan akurat dan komprehensif. Jika kebijakan kriminal mengenai penanggulangan kejahatan dan peradilan pidana benar-benar komprehensif, menangani semua aspek yang relevan, bukan hanya faktor masalah yang terkait peradilan pidana. Menganalisis secara komprehensif penyebab khusus dari kepadatan narapidana di lembaga pemasyarakatan dalam konteks apapun dan mengatasi penyebab yang mendasari kejahatan dan hukuman penjara adalah penting bagi keberhasilan strategi jangka panjang yang bertujuan untuk mengurangi 
tingkat kepadatan narapidana di lembaga pemasyarakatan dan penjatuhan pidana penjara. Faktor ini diakui oleh Rekomendasi yang diusulkan dalam The Seventh United Nations Congres on the Prevention of Crime and the Treatment of Offenders (1985 di Milan, Italia).

Lembaga pemasyarakatan merupakan tahap akhir sistem pemindanaan dan bagian dari penegakan hukum pidana di Indonesia sebagai pelaksana pidana penjara di Indonesia. Kedudukan lembaga pemasyarakatan merupakan Unit Pelaksana Teknis dibawah dibawah pengawasan Menteri Hukum dan HAM Republik Indonesia dilaksanakan oleh Direktorat Jendral Pemasyarakatan. Lembaga pemasyarakatan merupakan tempat untuk membina narapidana untuk menjadi masyarakat seutuhnya berdasarkan Pancasila dan UndangUndang Dasar Republik Indonesia Tahun 1945.

Kebijakan strategi Kementerian Hukum dan HAM Republik Indonesia disampaikan dalam rapat kerja Komisi III Dewan Perwakilan Rakyat Republik Indonesia dengan Menteri Hukum dan HAM Republik Indonesia pada tanggal 21 Januari 2015. Laporan singkat rapat kerja tersebut memberikan kesimpulan terkait strategi dalam meneruskan agenda yang telah ada dan menyelesaikan berbagai masalah yang dirasa masih timbul, salah satunya upaya mengatasi kepadatan narapidana di lembaga pemasyarakatan antara lain: membangun lembaga pemasyarakatan baru atau menambah kapasitas dengan gedung baru, mempercepat program reintegrasi sosial, mengadakan redistribusi narapidana, memperkuat forum MAHKUMJAKPOL (Mahkamah Agung, Kejaksaan, Kepolisian dan Kementerian Hukum dan HAM), menerapkan prinsip restorative justicemelalui proses diversi terutama pada kasus anak berhadapan dengan hukum (ABH). ${ }^{22}$

Kebijakan reintegrasi bagian dari sistem peradilan pidana dan merupakan amanat dari peraturan perundang-undangan. Kebijakan mempercepat reintegrasi yang mempercepat narapidana keluar dari lembaga pemasyarakatan akan mengurangi pengaruh budaya penjara (prisonisasi) yang cenderung negatif. Disamping mengurangi kepadatan, juga akan mengurangi biaya makan dan perawatan narapidana sehingga dapat menekan pengeluaran negara.

\footnotetext{
${ }^{22}$ Dewan Perwakilan Rakyat Republik Indonesia, Laporan Singkat Rapat Kerja Komisi III dengan Menteri Hukum dan HAM Republik Indonesia, (Jakarta: Dewan Perwakilan Rakyat), 2015, diakses pada tanggal 3 Januari 2015, www.dpr.go.id
} 
2. Upaya Mengurangi Kepadatan Narapidana dalam Lembaga Pemasyarakatan di Indonesia yang Akan Datang

\subsection{Perumusan Good Time Allowance sebagai Upaya Mengurangi Kepadatan Narapidana dalam Lembaga Pemasyarakatan Di Beberapa Negara Asing}

Kajian perbandingan merupakan usaha untuk menemukan gagasan di dalam melakukan perkembangan hukum yang dikehendaki. Perbandingan hukum juga merupakan suatu studi atau kajian perbandingan mengenai konsepsi-konsepsi intelektual) yang ada di balik institusi/ lembaga hukum yang pokok dari atau beberapa sistem hukum asing, sebagaimana pendapat E. Ewald, bahwa perbandingan hukum pada hakikatnya merupakan kegiatan yang bersifat filosofis (comparative law is an essentially philosohical activity). ${ }^{23}$

Berkaitan dengan kegiatan komparasi mengenai upaya mengurangi kepadatan narapidana di lembaga pemasyarakan dalam pembahasan ini, peneliti mengusulkan Good Time Allowance sebagai upaya mengurangi kepadatan narapidana di lembaga pemayarakatan. Oleh karena itu penulis melakukan kajian komparasi dengan beberapa negara asing antara yang mengatur Good Time

\footnotetext{
${ }^{23}$ W. Ewald, dalam Barda Nawawi Arief, Perbandingan Hukum Pidana, Op. cit., halaman 3.
}

Allowance, antara lain: Montana (Amerika Serikat), Wyoming (Amerika Serikat), dan Republik Filipina. Perumusan good time allowance di beberapa negara ini dapat digunakan dalam program pembinaan narapidana di Indonesia di masa akan datang sebagai variasi alternatif pembinaan narapidana di lembaga pemasyarakatan.

Ketentuan yang terdapat dalam good time allowance yang merupakan tindakan noncustodial setelah pemidanaan. Tujuan good time allowance sebagaimana yang dikemukakan Barda Nawawi Arief merupakan sarana individualisasi sanksi dan rehabilitasi narapidana. Dengan demikian, adanya model Good Time Allowance ini hanya mengurangi masa narapidana menjalani pidana dalam lembaga pemasyarakatan, bukan mengurangi masa pidana itu sendiri. Berdasarkan tujuan pemidanaan tersebut sejalan dengan ide dan tujuan pemasyarakatan. Patut dipertimbangkan bahwa, sistem pembinaan good time allowance seyogyanya dapat diterapkan di Indonesia sebagai pembaharuan program pembinaan narapidana.

\subsection{Korelasi Rancangan Kitab Undang- Undang Hukum Pidana 2015 dalam Upaya Mengurangi Kepadatan Narpaidana}

Berikut beberapa substansi pokok RKUHP tahun 2015, antara lain: 
1. Pergeseran filosofi pemidanaan jika dibandingkan dengan KUHP warisan pemerintah kolonial Belanda (wetboek van Strafrecht voor Nederlandsch Indie) sehingga RUU KUHP ini berorientasi pada pemikiran aliran neo classical school yang selain mempertimbangkan aspek tindak pidana yang telah dilakukan juga mempertimbangkan aspek individualitas pelaku tindak pidana (daad-dader straf recht).

2. Pengaturan mengenai tindak pidana dan pemidanaan berdasarkan hukum yang hidup dalam masyarakat sesuai dengan nilai-nilai Pancasila, hak azasi manusia, dan prinsipprinsip hukum umum yang diakui oleh masyarakat internasional.

3. Modernisasi hukum pidana nasional dengan menegaskan pengaturan bahwa korporasi merupakan subjek hukum pidana sehingga dianggap mampu melakukan tindak pidana dan dapat dipertanggungjawabkan secara pidana.

4. Adanya penambahan beberapa jenis pidana baru yakni pidana pengawasan dan pidana kerja sosial sebagai pidana pokok serta pembayaran ganti kerugian dan pemenuhan kewajiban adat setempat sebagai pidana tambahan.

5. Pidana mati tidak lagi diatur sebagai pidana pokok, melainkan diatur dalam pasal tersendiri untuk menunjukan bahwa pidana mati betul-betul bersifat khusus sebagai upaya terakhir (ultimum remedium) untuk mengayomi masyarakat. Pidana mati adalah pidana yang paling berat dan harus selalu diancamkan secara alternatif dengan jenis pidana seumur hidup atau pidana penjara paling lama 20 (dua puluh) tahun. Pidana mati dapat dijatuhkan pula secara bersyarat, dengan memberikan masa percobaan, sehingga dalam tenggang waktu masa percobaan tersebut terpidana diharapkan dapat memperbaiki diri sehingga pidana mati tidak perlu dilaksanakan, dan dapat diganti dengan pidana perampasan kemerdekaan.
6. Adanya beberapa perubahan konsep pemidanaan, antara lain:

a. Dianutnya sistem 2 (dua) jalur (doubletrack) yakni selain jenis-jenis pidana, diatur pula jenis-jenis sanksi tindakan (maatregelen) khusus bagi mereka yang melakukan tindak pidana, namun tidak atau kurang mampu mempertanggungjawabkan perbuatannya karena menderita gangguan jiwa atau retardasi mental.

b. Diaturnya rambu-rambu pemidanaan baru guna menghindari disparitas pidana terhadap tindak pidana yang relatif sama kualitasnya serta pengaturan mengenai pidana minimim khusus yang hanya boleh diterapkan untuk tindak pidana tertentu yang dipandang sangat merugikan, membahayakan, atau meresahkan masyarakat, dan untuk tindak pidana yang dikualifikasikan atau diperberat oleh akibatnya.

c. Adanya sistem kategorisasi pidana denda guna mengantisipasi flutuasi nilai mata uang akibat situasi prekonomian, dan

d. Diaturnya cara pelaksanaan secara khusus terhadap anak, sejalan dengan konvensi tentang Hak-Hak anak (Convention on the Rights of the Child)

7. Adaptasi dan harmonisasi terhadap perkembangan tindak pidana di luar KUHP dan berbagai tindak pidana yang bersumber dari berbagai konvensi internasional yang telah diratifikasi oleh Indonesia. Dengan demikian, terhadap jenis tindak pidana baru yang akan muncul namun belum diatur dalam RUU KUHP yang baru ini, pengaturannya tetap dapat dilakukan melalui perubahan KUHP atau diatur dalam UndangUndang tersendiri karena kekhususannya berdasarkan buku kesatu Pasal 211 RUU tentang KUHP ini. ${ }^{24}$

\footnotetext{
24 Kementerian Hukum dan HAM Republik Indonesia, (Jakarta: kementrian Hukum dan HAM), diakses pada tanggal 21 Desember 2015, www.kemenkumham.go.id
} 
Berdasarkan substansi pokok di atas terdapat substansi yang dapat digunakan sebagai upaya mengurangi kepadatan narapidana di lembaga pemasyarakatan masa akan datang dalam Rancangan Kitab UndangUndang Hukum Pidana (RKUHP) Tahun 2015. Upaya mengurangi kepadatan dalam RKUHP antara lain memasukkan rekomendasi PBB dalam mengurangi pidana custodial dengan menggunakan pidana non-custodial.

Bentuk terintegrasinya antara sistem pemasyarakatan dengan tujuan dan pedoman pemidanaan dapat dilihat dari adanya pedoman pemidanaan dan tujuan pemidanaan memberikan suatu pedoman dan arah kebijakan dengan memperhatikan rasa keadilan serta rasa kemanusiaan bagi korban, masyarakat dan pelaku kejahatan di dalam RKUHP Tahun 2015.

\subsection{Good Time Allowance (Pengurangan Masa Menjalani Pidana dengan Melakukan Suatu Pekerjaan Baik) Sebagai Upaya Alternatif Mengurangi Kepadatan Narapidana di Lembaga Pemasyarakatan yang Akan Datang}

Dalam penelitian ini penulis memberikan ide gagasan program pembinaan good time allowance sebagai sumbangan pembaharuan hukum pidana bidang pelaksana pidana untuk menanggulangi kepadatan narapidana upaya alternatif lain mengurangi/ pemotongan lama narapidana menjalani pidana penjara. Model Good Time Allowance (GA). Good Time Allowance ini bisa dijadikan cara untuk mengurangi adanya kepadatan lembaga pemasyarakatan yang selama ini terjadi.

Model Good Time Allowance juga mengarahkan pada sisi pelaku (narapidana) selama dalam pembinaan di lembaga pemsyarakatan juga mempunyai hak untuk mengajukan pengurangan masa pidana dengan melakukan pekerjaan yang baik tersebut. Good Time Allowance dapat digunakan dalam kebijakan kriminal dalam menanggulangi kejahatan dengan hukum pidana dengan tujuan perbaikan individu narapidana dengan diberikan motivasi untuk berubah memperbaiki kepribadianya menjadi baik di lembaga pemasyarakatan. Hal tersebut sesuai tujuan pemidanaan dan tujuan pemasyarakatan.

Pengurangan masa pidana dengan melakukan suatu pekerjaan baik dapat dijadikan sebagai sarana preventif (pencegahan) bagi narapidana untuk mengulangi tindak pidana, karena selama menjalani pembinaan setiap narapidana termotivasi dengan melakukan suatu pekerjaan baik.Pengurangan masa menjalani pidana dengan melakukan suatu pekerjaan baik merupakan ketentuan pelaksana pidana penjara melalui program pembinaan narapidana di dalam maupun diluar lembaga pemasyarakatan dengan melakukan program pekerjaan di tempat 
yang disediakan pemerintah atau lembaga sosial.

Upaya hukum tidak akan menghentikan pemberian pengurangan masa menjalani pidana dengan melakukan suatu pekerjaan baik.Pengurangan masa menjalani pidana dengan melakukan suatu pekerjaan baik tidak diberikan kepada narapidana yang melarikan diri, Narapidana sakit mental dan bagi narapidana yang diancam dengan pidana minimum khusus, narapidana yang diancam dibawah pidana 1 tahun atau pidana kurungan dan untuk pembinaan di luar lembaga pemasyarakatan tidak untuk narapidana yang diancam dibawah 5 tahun pidana penjara.

Narapidana yang melakukan pekerjaan baik mendapatkan penghargaan atau upah pengurangan masa menjalani pidana dengan ketentuan 2 hari bekerja mendapatkan pengurangan selama 1 hari atau minimum pengurangan menjalani masa pidana 1 hari sampai dengan maksimum 15 hari per bulan. Ketentuan lama waktu penguranan masa pidana dengan melakukan suatu pekerjaan baik adalah bekerja selama 7 jam per hari selama 6 hari atau bekerja 42 jam selama satu minggu. Pengurangan masa menjalani pidana denganmelakukan suatu pekerjaan baik tidak dilaksanakan pada hari minggu dan hari libur dan hari besar nasional yang ditetapkan pemerintah.

\section{KESIMPULAN DAN SARAN}

\section{Simpulan}

Strategi Kementerian Hukum dan HAM Republik Indonesia sebagai operator pelaksana dalam upaya mengurangi kepadatan narapidana di lembaga pemasyarakatan Upaya-upaya yang dilakukan selama ini belum maksimal dalam menanggulangi kepadatan narapidana di lembaga pemasyarakat karena masih terjadi kepadatan narapidana dalam lembaga pemasyarakatan di Indonesia.

Upaya alternatif mengurangi kepadatan narapidana di lembaga pemasyarakatan yang akan datang dapat ditempuh dengan membuat program pembinaan narapidana Pengurangan masa menjalani pidana dengan melakukan suatu pekerjaan baik merupakan ketentuan pelaksana pidana penjara melalui program pembinaan narapidana di dalam maupun diluar lembaga pemasyarakatanyang di sediakan pemerintah atau lembaga sosial. Narapidana yang melakukan pekerjaan baik mendapatkan penghargaan atau upah pengurangan masa menjalani pidana dengan ketentuan 2 hari bekerja mendapatkan pengurangan menjalani masa pidana selama 1 hari atau minimum pengurangan menjalani masa pidana 1 hari sampai dengan maksimum 15 hari per bulan. Ketentuan lama waktu penguranan masa pidana dengan melakukan suatu pekerjaan baik adalah 
bekerja selama 7 jam per hari selama 6 hari atau bekerja 42 jam selama satu minggu.

\section{Saran}

Adanya strategi kebijakan di lembaga pemasyarakatan untuk membantu rehabilitasi narapidana untuk menyiapkan proses resosialisasi dengan mengupayakan kegiatankegiatan positif yang dapat membantu narapidana tersebut.

Adanya upaya memperkuat program pembinaan mempercepat reintegrasi narapidana untuk mengurangi kepadatan narapidana di lembaga pemasyarakatan dengan melahirkan kebijakan yang fleksibel sehingga permasalahan kepadatan narapidana akan teratasi dengan pengurangan masa menjalani pidana dengan melakukan pekerjaan baik.

\section{DAFTAR PUSTAKA}

\section{Buku}

Arief,Barda Nawawi, 2002.Perbandingan Hukum Pidana. Jakarta: Raja Grafindo Persada

' 2013,Kapita Selekta Hukum

Asshiddiqie,Jimly,2005,Konstintusi dan Konstitusionalisme,Jakarta: Konstitusi Press

Cavadino, Michael, and James Dignan,2003,The Penal System an Introduction,London: Sage Publications

Dicey,A.V.,1973,An Introduction to The Study of The Law of The Constitution, $10^{\text {th }}$ ed. London: Macmillan Press
Effendi,A., Mansyur, 2005, Perkembangan Dimensi Hak Asasi Manusia dan Proses Dinamika penyusunan Hukum Hak Asasi Manusia,Bogor: Ghalia Indonesia

Ibrahim,Johnny, 2010, Teori dan Metode Penelitian Normatif,Malang: Bayumedia Publishing

Marbun,S.F., 2001,Dimensi-Dimensi Pemikiran Hukum Administrasi Negara,Yogyakarta: UUI Perss

Marzuki,Peter Mahmud, 2014,Penelitian Hukum,Jakarta: Kencana Prenada Media

Nyoman Serikat Putra Jaya,1989,Beberapa Permasalahan dalam Sistem Pemidanaan dalam Konsep KUHP Baru, Majalah Fakultas Hukum Universitas Diponegoro No. 1, Semarang: Fakultas Hukum Universitas Diponegoro

Priyatno, Dwidja,2013,Sistem Pelaksana Pidana Penjara di Indonesia,Bandung: Refika Aditama

Soponyono, Eko, 2015,Realitas Penjara Indonesia 2,Jakarta: Center for Detention Studies

Sudarto, 1981,Kapita Selekta Hukum Pidana,Bandung: Alumni

Syamsudin,M., 2007,0perasionalisasi Penelitian Hukum.,Jakarta: Raja Grafindo Persada

Wignjosoebroto,Soetandyo, 2002,Hukum Paradigma, Metode dan Dinamika Masalahnya,Jakarta: Elsam dan Huma

Internet

Dewan Perwakilan Rakyat Republik Indonesia, Laporan Singkat Rapat Kerja Komisi III dengan Menteri Hukum dan HAM Republik Indonesia, (Jakarta: Dewan Perwakilan Rakyat), 2015, diakses pada tanggal 3 Januari 2015, http://www.dpr.go.id

Kementerian Hukum dan HAM Republik Indonesia, Penyempurnaan RUU KUHP, (Jakarta: kementrian Hukum dan HAM), diakses 
pada tanggal 21 Desember 2015, http://www.kemenkumham.go.id

Kementerian Pemberdayagunaan Aparatur Negara dan Reformasi Birokrasi, Tenaga Administrasi akan Dialihkan Menjadi Sopir, (Jakarta: Kemenpan), diakses pada tanggal $21 \quad$ Mei 2015, http://www.menpan.go.id

\section{Undang-Undang}

Undang-Undang Dasar Republik Indonesia Tahun 1945 